\title{
A Multiplex-PCR Method for Strain Identification and Detailed Phylogenetic Analysis of AY-Group Phytoplasmas
}

Shigeyuki Kakizawa and Yoichi Kamagata, Bioproduction Research Institute, National Institute of Advanced Industrial Science and Technology (AIST), Tsukuba, Ibaraki 305-8566, Japan

\begin{abstract}
Kakizawa, S., and Kamagata, Y. 2014. A multiplex-PCR method for strain identification and detailed phylogenetic analysis of AY-group phytoplasmas. Plant Dis. 98:299-305.

Phytoplasmas are plant pathogenic bacteria that cause devastating losses in the yield of diverse crops worldwide. Specific detection and strain identification of phytoplasmas is important to prevent the spread of phytoplasma-induced diseases. Hence, methods to rapidly detect these organisms are important for pest control. Polymerase chain reaction (PCR) methods using phytoplasma-specific primers are widely used to detect phytoplasmas from infected plants and insects because they are highly sensitive, easily handled, and have a variety of analytical secondary applications. The phytoplasma 16S rDNA was widely used as a target of the PCR detection method; however, further target genes and more rapid methods have been required for more specific detection of phytoplasmas. Here, we developed a multiplex-PCR system to amplify several phytoplasma genes. We designed 36 primers, based on the genome sequence of 'Candidatus Phytoplasma asteris', to

amplify 18 single-copy genes covering wide regions of the phytoplasma genome. Nine genes could be simultaneously amplified in a single PCR. This multiplex-PCR was applied to DNAs from 10 phytoplasma strains belonging to the AY-group, and different amplification patterns were obtained between strains, suggesting that this method would allow us to differentiate phytoplasmas at the strain level. Direct sequencing was also possible after the multiplex-PCR amplification by a modified sequencing method. Detailed phylogenetic analysis was performed using concatenated sequences, and evolutionary relationships among four Japanese isolates were revealed, where these strains could not be distinguished by their $16 \mathrm{~S}$ rDNA. Thus, this multiplexPCR system is useful for rapid strain identification and detailed phylogenetic analysis of phytoplasmas.
\end{abstract}

Phytoplasmas are plant pathogenic bacteria that cause diseases in several hundred plant species and significant yield loss in crop production $(4,12,17,36)$. Phytoplasmas infect the phloem sieve elements of plants and are transmitted between plants by phloemfeeding insect hosts (17). Plants infected with phytoplasmas show characteristic symptoms, such as yellowing, proliferation, and stunting. Phytoplasmas usually do not kill the host plants in a short period of time, but phytoplasma-infected plants become more susceptible to infection by other pathogens such as fungi and viruses. Thus, the possibility of epidemic spreading of phytoplasmas as well as other pathogens is of great concern (4). Despite their detrimental traits, phytoplasmas remain the most poorly characterized plant pathogen because of their uncultivability.

To date, more than several hundred phytoplasma strains have been reported worldwide, and these strains have been classified into more than 30 'Candidatus phytoplasma' species. Among them, genomes of four strains have been completely sequenced $(1,26,43,51)$, and high-quality draft genome sequences of four phytoplasma strains have been obtained (45). The plant host range of each phytoplasma strain is quite large, e.g., aster yellows phytoplasma can infect 161 plant species within 120 genera and 39 families (36). In contrast, host range of insect vectors that carry phytoplasmas is usually narrow and varies among strains, i.e., each phytoplasma strain could be transmitted by specific insect species $(17,42,46)$. Degrees of pathogenicity are also different between strains, and therefore, information about phytoplasma strains is critical to ascertain its pathogenicity and spreading capacity. Thus, detection and strain-identification of phytoplasmas is important to prevent the

Corresponding author: Shigeyuki Kakizawa,

E-mail: s.kakizawa@aist.go.jp

Accepted for publication 27 September 2013.

http://dx.doi.org/10.1094/PDIS-03-13-0216-RE

(C) 2014 The American Phytopathological Society spread of phytoplasma diseases; rapid detection techniques are critical for this process.

Several methods of phytoplasma detection have been developed thus far, including polymerase chain reaction (PCR) with phytoplasmaspecific primers $(29,35,38,53)$, enzyme-linked immunosorbent assay (ELISA) (2), Western blotting $(2,5,22,24,39)$, microscopic analyses using DAPI or related dye $(8,9,27)$, immunohistochemical analysis $(23,52)$, and loop-mediated isothermal amplification (LAMP) method $(3,16,41,49,54)$. PCR is advantageous among these techniques because it is highly sensitive and easily handled. In addition, it can have several secondary analytical applications such as restriction fragment length polymorphism (RFLP) analysis, direct sequencing, and phylogenetic analyses. Several phytoplasma genes have been successfully reported as PCR targets, including genes encoding $16 \mathrm{~S}$ rDNA $(15,18)$, ribosomal proteins $(10,20,28,29,50)$, the protein secretion machinery SecY $(10,28,31)$, the elongation factor TufB $(30,33,35)$, and the molecular chaperon GroEL (37). Thus, PCR would be the most powerful tool for detection of phytoplasmas. Further target genes and more rapid methods are required for the specific detection of phytoplasmas.

Multiplex-PCR is a PCR method that amplifies multiple DNA fragments in a single reaction $(7,11)$. This method has been used to detect several pathogens or genes in 1 PCR reaction $(6,11,13$,

Table 1. Phytoplasma strains used in this study

\begin{tabular}{|c|c|c|c|}
\hline Acronym & Description & $\begin{array}{l}\text { Country } \\
\text { of origin }\end{array}$ & $\begin{array}{l}\text { 16S RFLP } \\
\text { groups }\end{array}$ \\
\hline OY-W & Onion yellows & Japan & 16SrI-B \\
\hline MD & Mulbery dward & Japan & 16SrI-B \\
\hline CJW & $\begin{array}{l}\text { Cryptotaenia japonica } \\
\text { witches'-broom }\end{array}$ & Japan & 16SrI-B \\
\hline GD & Dogwood yellows & New York, USA & 16SrI-A \\
\hline AAY & American aster yellows & Florida, USA & 16SrI-B \\
\hline $\mathrm{CCh}$ & Cabbage chlorantie & France & 16SrI-B \\
\hline $\mathrm{CA}$ & Carrot yellows & Italy & $16 \mathrm{SrI}-\mathrm{C}$ \\
\hline AY-A & Aster yellows from apricot & Spain & 16SrI-F \\
\hline BA & From unknown insects & Italy & 16SrXII-A \\
\hline ASLO & Aster yellows & Slovenia & 16SrXII-A \\
\hline
\end{tabular}


Table 2. Polymerase chain reaction primers used in this study

\begin{tabular}{|c|c|c|}
\hline Name & Sequence & Length \\
\hline A1_F & ccgctatatatttttggaaaagcagga & 27 \\
\hline A1_R & catttgagttcttgtagcacctgcc & 25 \\
\hline $\mathrm{A} 2 \_\mathrm{F}$ & atccagttttgecatcccea & 20 \\
\hline A2_R & tcttccaacagccaaacctgaac & 23 \\
\hline A3_F & cccacgcttctaatgtaggcattg & 24 \\
\hline A3_R & aacagctgcttgtgttgttggc & 22 \\
\hline A4_F & gcgcgaagttgacaaacctttc & 22 \\
\hline A4_R & taattcagcgttgtcacctggc & 22 \\
\hline A5_F & ttggcaaatgcagctaattcctt & 23 \\
\hline A5_R & cactgcctgctcctagttccaaaa & 24 \\
\hline A6_F & ggtggcggacattttaatcattct & 24 \\
\hline A6_R & agcgaatgattgetctgtctactttg & 26 \\
\hline A7_F & gacgaatccagtcgcaaaggaa & 22 \\
\hline A7_R & ttcataccagaaacgcettgec & 22 \\
\hline A8_F & cggataagaacctaatcgcagggt & 24 \\
\hline A8_R & ccatcagacaagtgcgctttga & 22 \\
\hline A9_F & ggacctgcttcgctcattgttaag & 24 \\
\hline A9_R & ccttttgatcctgctttgcacc & 22 \\
\hline B1_F & aatcgcacactccaagaaactgc & 23 \\
\hline B1_R & catgttaggtcttgcattaggatttgc & 27 \\
\hline B2_F & ggaattgtagttggtggtggaaaagc & 26 \\
\hline $\mathrm{B} 2 \_\mathrm{R}$ & catcaaagcagagatagaagcagca & 25 \\
\hline B3_F & tgctactgcaggagttgctgtttt & 24 \\
\hline B3_R & ctcctgctaacatctggaaaggttg & 25 \\
\hline B4_F & geccettgagctaaactagcatt & 24 \\
\hline B4_R & cgacttgcaccaactaacccaa & 22 \\
\hline B5_F & ttttgaaaacgacaaagaaactgga & 26 \\
\hline B5_R & atgggaccatcgccacgataat & 22 \\
\hline B6_F & tatcagaagaaccggaaccacctg & 24 \\
\hline B6_R & cgctgtatgcttggaaacttgc & 22 \\
\hline B7_F & tagcaacgaacctaccaaaccagg & 24 \\
\hline B7_R & ctcttccttggggaaaaacagacc & 24 \\
\hline B8_F & tcactttcaggagtacttgcaggc & 24 \\
\hline B8_R & ggttaaagctttgagtggggttgc & 24 \\
\hline B9_F & attgatgtggatgecttctcec & 22 \\
\hline B9_R & ttgggattcatttgggctgc & 20 \\
\hline
\end{tabular}

25,48). Secondary analytical applications are also possible after multiplex-PCR (32,34). Several multiplex-PCR kits are commercially available. More than 15 fragments can be successfully amplified in 1 reaction (6), and fragments as large as $2.0 \mathrm{kbp}$ can also be amplified. In addition, the combinations of primers can be easily modified. Thus, this is an easy, rapid, and specific method for the amplification of multiple target genes.

Here, we developed a multiplex-PCR system to amplify 18 phytoplasma gene fragments in 2 PCR reactions. All genes were successfully amplified in the majority of $16 \mathrm{SrI}$ group phytoplasmas, and direct sequencing was also possible for all gene fragments. Results obtained in this study suggest that the multiplex-PCR system is useful for rapid strain identification and detailed phylogenetic analysis of AY-group phytoplasmas.

\section{Materials and Methods}

Phytoplasma DNAs. All phytoplasma strains used in this study are listed in Table 1. Plant tissues infected with onion yellows line W (OY-W), mulberry dwarf (MD), and Cryptotaenia japonica witches'-broom phytoplasmas (CJW) were kindly provided by Dr. Nishimura and Dr. Nakajima (Koibuchi College of Agriculture and Nutrition, Japan) (40). Total DNAs were extracted by the normal CTAB method as described previously (21). DNA samples extracted from dogwood yellows (GDI), American aster yellows (AAY), cabbage chlorantie (CCh), carrot yellows (CA), aster yellows from apricot (AY-A), and aster yellows (ASLO) phytoplasmas and an unknown insect (BA) were kindly provided by Dr. Bertaccini (University of Bologna, Italy). These phytoplasmas belong to $16 \mathrm{Sr}-\mathrm{I}$ or $16 \mathrm{Sr}-\mathrm{XII}$. The presence of phytoplasma DNAs in all of these samples were checked by PCR amplification of phytoplasma $16 \mathrm{~S}$ rDNA (data not shown).

Multiplex-PCR amplification. Multiplex-PCR was performed using a Qiagen multiplex PCR kit (Qiagen, Japan), according to

Table 3. Target genes of multiplex-polymerase chain reaction (PCR) and summary of multiplex-PCR results

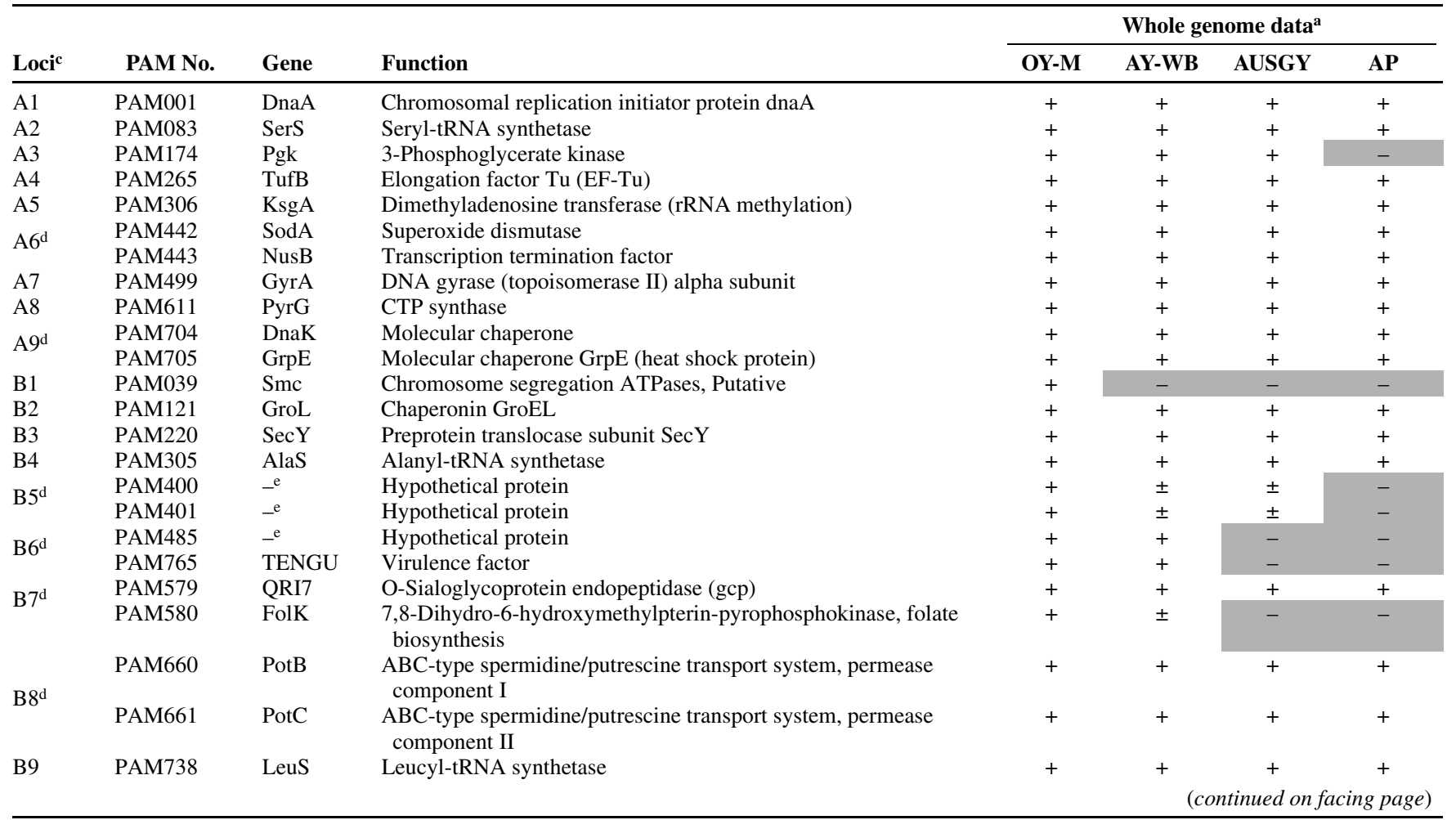

a Homologues of target genes were searched by BLAST from 4 completely sequenced phytoplasma genomes.,,+- and \pm represent that a homologue was found, not found, and several homologues were found, respectively.

${ }^{\mathrm{b}}$ Results of multiplex-PCR amplifications. Each number represents the accession numbers of each amplified fragment. -: not amplified.

${ }^{c}$ Eighteen loci were selected as targets for multiplex-PCR.

d Six primer sets were constructed to anneal between two genes.

e Hypothetical protein genes. 
the manufacturer's instructions with an annealing temperature of $55^{\circ} \mathrm{C}$. Total volume of the multiplex-PCR was usually $15 \mu \mathrm{l}$. PCR products were separated by electrophoresis with $2 \%$ agarose gel. As a DNA marker of electrophoresis, LoadingQuick 100-bp DNA Ladder (Toyobo, Japan) was used. In single PCR analyses, only 1 primer set was added, and other conditions were completely similar to those of the multiplex-PCR.

Direct sequencing of multiplex-PCR products. PCR-amplified fragments were purified using ExoSAP-IT (GE Healthcare Japan), which inactivates primers and nucleotides by using exonuclease and shrimp alkaline phosphatase. Alternatively, fragments were purified by magnetic bead purification using the Agencourt AMPure XP system (Beckman Coulter). Cycle sequencing reactions were performed using a BigDye Terminator v3.1 Cycle Sequencing Kit (Applied Biosystems). In cycle sequencing reactions, 0.5 to 3.0 $\mu \mathrm{g}$ template DNA/reaction was used. This amount of template DNA was about one-tenth that used in normal conditions. The reaction products were purified using a magnetic bead purification system, Agencourt CleanSEQ (Beckman Coulter). An ABI 3130xl Genetic Analyzer (Applied Biosystems) was used for sequencing. Primers for sequencing reactions were the same as those used in PCR.

Tree construction. Sequences of all amplicons generated from 10 strains listed in Table 1 plus OY-M and AY-WB from wholegenome sequencing data (GenBank accession numbers NC_005303.2 and NC_007716.1, respectively) were aligned by ClustalW (Thompson, Higgins and Gibson 1994). Ten genes were successfully amplified from all 16SrI phytoplasmas, and alignments of these 10 genes were concatenated. A phylogenetic tree was constructed with the concatenated data containing 5,119 nucleotide sites by the neighbor-joining method with the pairwise deletion model using MEGA 4 (47).

\section{Results}

Primer design. To identify target genes for multiplex-PCR, we used the whole genome sequence of 'Candidatus Phytoplasma asteris' OY-M strain, a member of the $16 \mathrm{SrI}-\mathrm{B}$ group of phytoplasmas (43). If primers anneal to several genes in a genome, several fragments would be amplified with one primer set; thus, all primers were designed to amplify single-copy genes. We chose 18 loci with single-copy genes, and designed 18 primer sets (36 primers) to amplify 18 fragments in two PCR reactions (Tables 2 and 3). Each A and B primer set included 18 primers to amplify 9 fragments in one PCR reaction. Figure 1 shows an illustration of the 'Candidatus Phytoplasma asteris' chromosome and the locations of all primers designed in this study. This circular chromosome illustration was drawn using GC viewer server (14). Amplified fragments were designed to have 80 to $100 \mathrm{bp}$ differences between each other so that they could be distinguished by electrophoresis (Fig. 1). Annealing temperatures of all primers were around $60^{\circ} \mathrm{C}$. All primers were designed using Primer3 software (44).

Table 3 shows the 18 loci and target genes. Most of the target genes were conserved and functionally important genes, including the chromosome replication gene DnaA, the elongation factor TufB (19), the chaperon protein GroEL, and a component of protein secretion system (SecY). In addition, some hypothetical genes were selected as target genes; thus, these target genes were a combination of conserved and nonconserved genes. Primers on A6, A9, B5, B6, B7, and B8 loci were designed to overlap two genes or a gene and an intergenic region.

Single (Uniplex) PCRs. Each of the 18 genes was first amplified separately with OY-W total DNA as a template. All fragments were successfully amplified (Fig. 2), and the size of these frag-

Table 3. (continued from previous page)

\begin{tabular}{|c|c|c|c|c|c|c|c|c|c|c|}
\hline \multirow{2}{*}{$\begin{array}{l}\text { Locic } \\
(\text { cont. })\end{array}$} & \multicolumn{10}{|c|}{ Multiplex PCR results ${ }^{b}$} \\
\hline & OY-W & MD & CJW & GD & AAY & $\mathrm{CCh}$ & CA & AY-A & BA & ASLO \\
\hline A1 & AB779218 & AB779236 & AB779252 & AB779269 & AB779282 & AB779297 & AB779313 & AB779325 & - & - \\
\hline A2 & AB779219 & AB779237 & AB779253 & AB779270 & AB779283 & AB779298 & AB779314 & AB779326 & - & - \\
\hline A3 & AB779220 & AB779238 & AB779254 & AB779271 & AB779284 & AB779299 & AB779315 & AB779327 & - & - \\
\hline A4 & AB779221 & AB779239 & AB779255 & AB779272 & AB779285 & AB779300 & AB779316 & AB779328 & AB779338 & AB779339 \\
\hline A5 & AB779222 & AB779240 & AB779256 & AB779273 & AB779286 & AB779301 & - & AB779329 & - & - \\
\hline $\mathrm{A} 6^{\mathrm{d}}$ & AB779223 & AB779241 & AB779257 & AB779274 & AB779287 & AB779302 & AB779317 & AB779330 & - & - \\
\hline A7 & AB779224 & AB779242 & AB779258 & AB779275 & AB779288 & AB779303 & AB779318 & AB779331 & - & - \\
\hline A8 & AB779225 & AB779243 & AB779259 & AB779276 & AB779289 & AB779304 & - & AB779332 & - & - \\
\hline$A 9^{d}$ & AB779226 & AB779244 & AB779260 & AB779277 & AB779290 & AB779305 & AB779319 & AB779333 & - & - \\
\hline B1 & AB779227 & - & AB779261 & - & - & - & - & - & - & - \\
\hline B2 & AB779228 & AB779245 & AB779262 & AB779278 & AB779291 & AB779306 & AB779320 & AB779334 & - & AB779340 \\
\hline B3 & AB779229 & AB779246 & AB779263 & AB779279 & AB779292 & AB779307 & AB779321 & AB779335 & - & - \\
\hline B4 & AB779230 & AB779247 & AB779264 & - & AB779293 & AB779308 & AB779322 & AB779336 & - & - \\
\hline$B 5^{\mathrm{d}}$ & AB779231 & - & - & - & - & - & - & - & - & - \\
\hline $\mathrm{B} 6^{\mathrm{d}}$ & AB779232 & AB779248 & AB779265 & AB779280 & - & AB779309 & - & - & - & - \\
\hline$B 7^{d}$ & AB779233 & AB779249 & AB779266 & - & AB779294 & AB779310 & AB779323 & - & - & - \\
\hline$B 8^{d}$ & AB779234 & AB779250 & AB779267 & AB779281 & AB779295 & AB779311 & AB779324 & AB779337 & - & - \\
\hline B9 & AB779235 & AB779251 & AB779268 & - & AB779296 & AB779312 & - & - & - & - \\
\hline
\end{tabular}


ments was identical to the predicted sizes. No nonspecific fragment was observed in all primer sets (Fig. 2), indicating the high specificity of all primer sets designed in this study.

Multiplex-PCRs. Multiplex-PCRs with A or B primer sets were performed using DNA from the 10 phytoplasma strains listed in Table 1. As shown in Figure 3, all 18 fragments were successfully amplified with OY-W total DNA by two PCR reactions, and all bands were clearly distinguished by electrophoresis on a $2 \%$ agarose gel. The sizes of all fragments were identical to the predicted sizes. A comparison of all the phytoplasma lanes showed that the patterns of amplification were different between strains, except for MD versus CCh. Results of multiplex-PCR amplification are summarized in Table 3. Among these 18 genes, conserved genes such as $t u f \mathrm{~B}$, groEL, and $\sec \mathrm{Y}$ tended to be commonly amplified. Especially, tufB was amplified from all phytoplasma strains tested. In contrast, hypothetical genes were amplified from only several phytoplasma DNA samples.

Direct sequencing and phylogenetic analyses. Direct sequencing was performed on multiplex PCR reactions using the gene-specific primers. At first, there was quite a high background signal in the electropherogram from the sequencing results because of the multiplex fragments in the template DNA. When the amount of template DNA in the cycle sequencing reaction step was reduced to one-tenth $(0.5-3.0 \mu \mathrm{g}$ template DNA per reaction) of that used under normal conditions, very clear results were obtained and all amplified fragments from the 10 phytoplasma strains were successfully sequenced. All gene fragments were confirmed to have homology with their respective target genes, indicating the high specificity of all primer sets designed in this study. All of these new 123 gene sequences were deposited to the GenBank database with accession numbers AB779218-AB779340 (Table 3).
Ten genes that were amplified from all 16SrI phytoplasmas were aligned and then concatenated, and a phylogenetic tree was constructed with the concatenated data containing 5,119 nucleotide sites (Fig. 4). This tree was in good agreement with previously constructed trees. In particular, 16SrI phytoplasmas were clustered together, indicating that the 16S RFLP grouping was supported by this tree.

\section{Discussion}

Phytoplasmas have a high degree of pathogenicity, and the host range is quite different between strains. Therefore, accurate strainidentification is important in phytoplasma epidemiology. So far, several methods to identify phytoplasma strains have been developed. Among them, RFLP or sequencing analyses of PCR-amplified $16 \mathrm{~S}$ rDNA has been found to be effective and is widely used. Here, we developed a multiplex-PCR method for strain identification of phytoplasma. This method would allow rapid strain identification and would enable closely related phytoplasma strains to be identified and distinguished following PCR and gel electrophoresis. Direct sequencing and subsequent phylogenetic analysis are also possible after multiplex-PCR. Although the method established in this study would be specific for AY-group phytoplasmas, similar multiplex-PCR systems could be developed in other phytoplasma groups by using the same procedures. Previously, a multiplex-PCR system was developed using species-specific primer sets to detect 10 'Candidatus Phytoplasma' species (25), and a multiplex-PCR system to detect plant viruses and phytoplasmas was developed by other groups (48). Taken together, these studies and our study prove that strain identification by multiplex-PCR could be a powerful tool for epidemiologic study of phytoplasmas.

Phylogenetic analysis using phytoplasma 16S rDNA sequences has been a powerful and useful method for clarifying the relation-

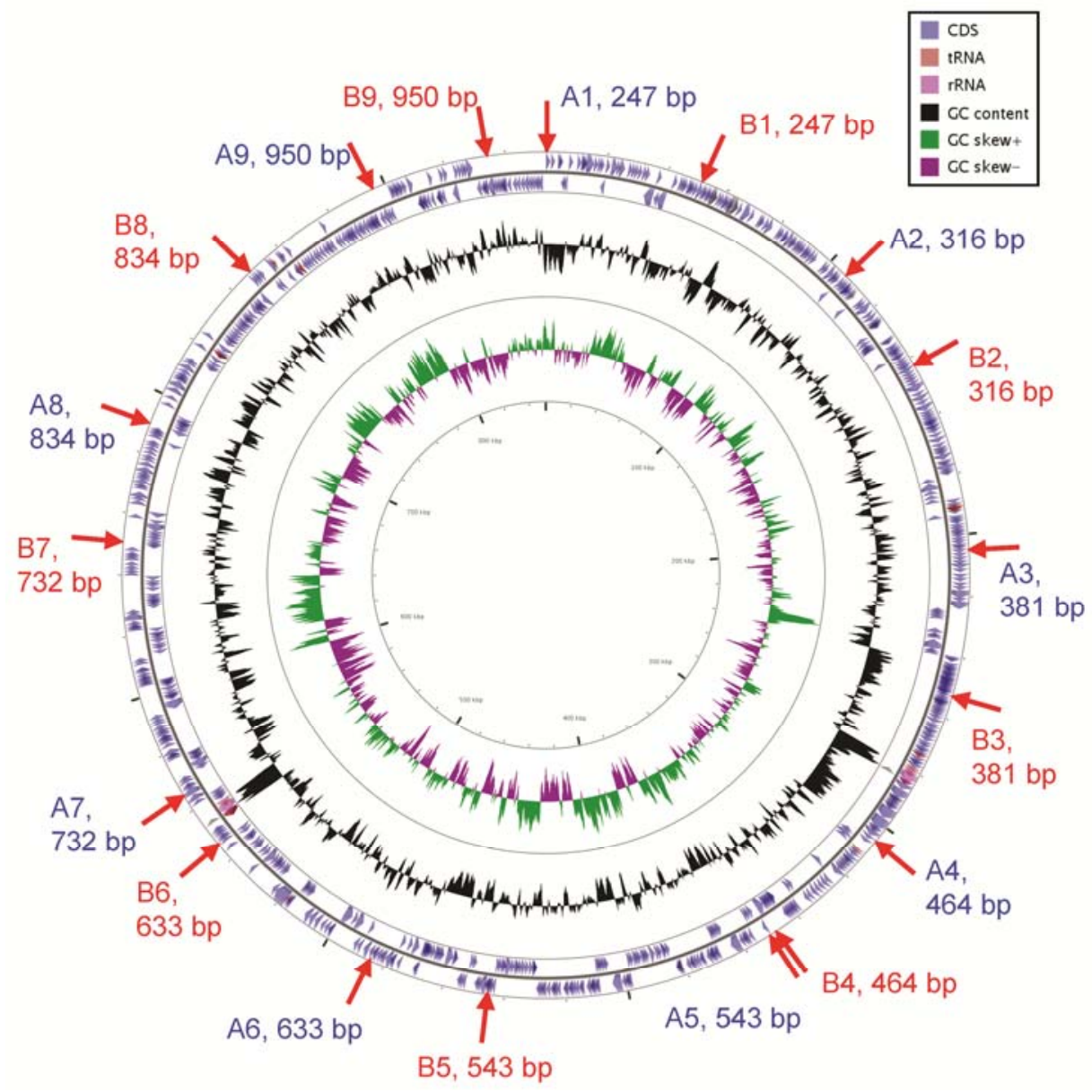

Fig. 1. An illustration of the 'Candidatus Phytoplasma asteris' chromosome and annealing loci of all primers designed in this study. Lengths of amplified fragments are also shown. 
ships and evolution of phytoplasmas. Sequence comparison analysis of 16S rDNA has also been useful in defining 'Candidatus Phytoplasma' species (18). Since $16 \mathrm{~S}$ rDNA sequences are highly conserved, highly reliable evolutionary analyses could be performed. However, 16S rDNA sequence data are insufficient when clarification of the phylogenetic relationships between closely related phytoplasma strains is required. Characteristics of phytoplasmas, e.g., host range, degrees of pathogenicity, and insect vectors, are quite different even between closely related strains; thus, detailed classification of phytoplasmas is necessary to understand the biology of phytoplasmas. To this end, several genes were reported to be able to give more detailed phylogenetic analyses, for example, genes encoding ribosomal proteins, SecY, TufB, and GroEL. Here, we performed detailed phylogenetic analyses of AY-group phytoplasmas by using concatenated data of 10 genes. This tree was in good agreement with previously constructed trees. In particular, the 16S RFLP grouping was supported by this tree.

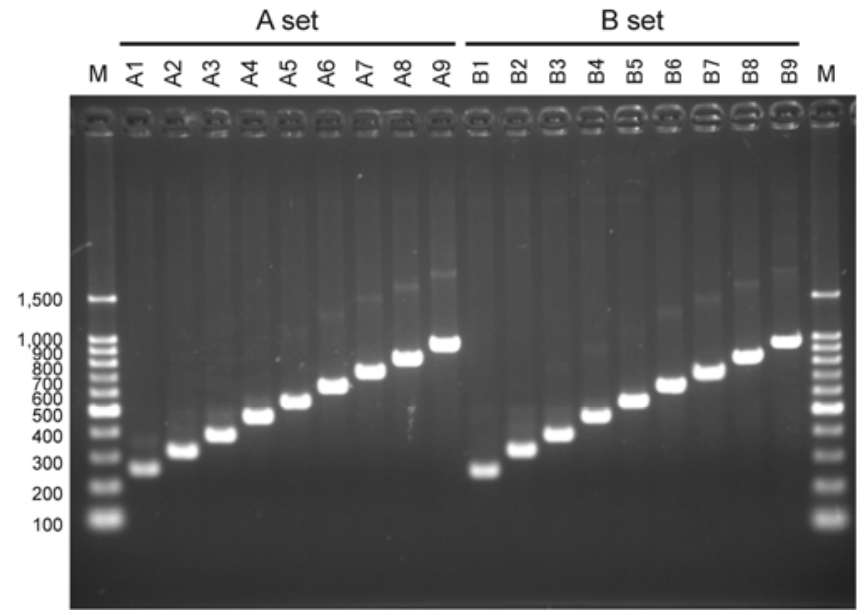

Fig. 2. Results from single polymerase chain reactions (PCR). PCR products were loaded onto a $2 \%$ agarose gel and visualized by EtBr and UV. Sizes of all bands were identical to the predicted sizes (from $247 \mathrm{bp}$ to $950 \mathrm{bp}$ ). M: DNA ladder marker (Toyobo LoadingQuick 100-bp DNA Ladder). DNA sizes of the marker lanes are shown on the left.
Through this detailed phylogenetic analysis, the evolutionary relationships among four Japanese isolates, OYW, OYM, MD, and CJW, were clarified by high bootstrap proportions: it was suggested that OYW was more closely related to CJW than to OYM, and MD was distantly related to these three strains. These four phytoplasmas could not be distinguished by $16 \mathrm{~S}$ rDNA data because their $16 \mathrm{~S}$ rDNA sequences were almost identical. These results suggest that this method could be useful for detailed phylogenetic analysis with finer resolution.

Although the multiplex-PCR is a simple and easy method, technical difficulties could occur if multiple bands or nonspecific bands are amplified by a primer set or combinations of different primer sets. This would make it extremely difficult to interpret the results. In this study, however, there was no nonspecific amplification in all single PCRs, and all multiplex-PCR fragments were clearly sequenced by the direct sequencing method, suggesting that no nonspecific amplification occurred. The reasons for this high specificity might be that the annealing temperature of each primer was designed to be high $\left(\mathrm{ca} .60^{\circ} \mathrm{C}\right)$ and all primers were designed on single-copy genes in the phytoplasma genome. The same strategies should be just as effective when adding further primers to this system.

Several genes were unamplified; however, this does not necessarily mean that these genes were absent in respective phytoplasmas. Rather, it is likely that several primers could not anneal with their target genes. For example, in BA and ASLO strains, only one

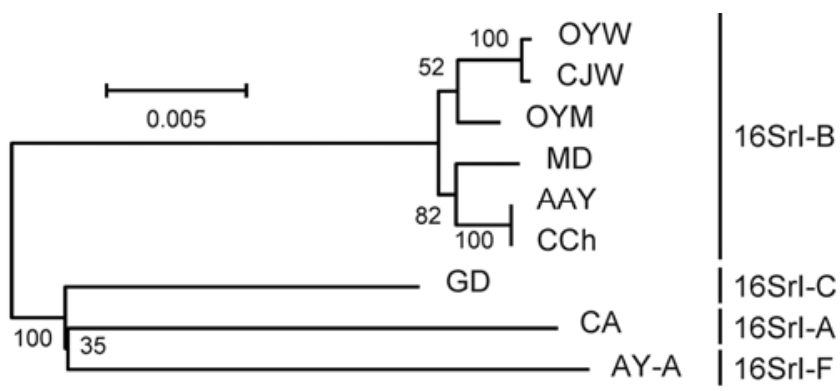

Fig. 4. A phylogenetic tree was constructed by the neighbor-joining method using concatenated data of 10 genes (5,119 nucleotide sites). Numbers on branches are the bootstrap values. The $16 \mathrm{~S}$ restriction fragment length polymorphism (RFLP) groupings are shown on the right. The phylogeny presented here is consistent with the previously established $16 \mathrm{~S}$ RFLP groupings.

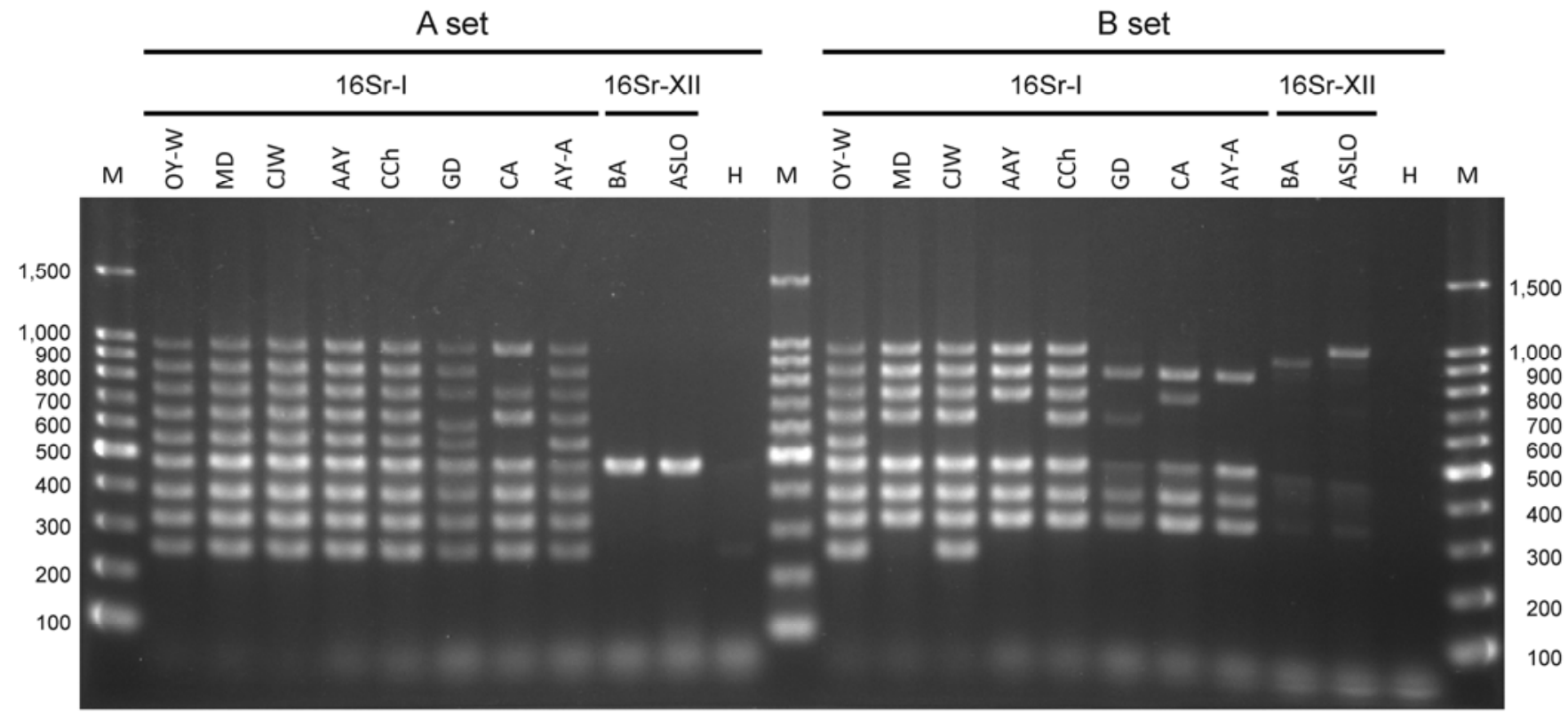

Fig. 3. Results from the multiplex-polymerase chain reactions (PCR). The multiplex-PCR products were loaded onto a $2 \%$ agarose gel and visualized by EtBr and UV. In OY-W lanes, 9 fragments were successfully amplified and clearly visualized by both A and B primer sets. In other phytoplasma lanes, the patterns of amplification were different between strains. M: DNA marker (Toyobo LoadingQuick 100-bp DNA Ladder). DNA sizes of each fragment on marker lane are shown. 
gene could be amplified by the A set (9 primer sets); however, it is unclear whether the other eight genes are present or absent in these two strains. Further analyses would be needed to reveal the presence of these genes in respective phytoplasmas. In addition, the multiplex-PCR method in this study has only the first step of PCR amplification, so the sensitivity of this method might be less than the nested-PCRs. Further analyses would be needed about the sensitivity of this method.

The multiplex-PCR system we developed could be applied to other phytoplasma groups. To apply the multiplex-PCR to other groups of phytoplasmas, it would be necessary to design appropriate primers for respective group of phytoplasmas and to examine amplification patterns with these new primers. For routine diagnostic testing, PCR with universal $16 \mathrm{~S}$ rDNA primers followed by sequence analysis should be carried out; however, the multiplexPCR method would be useful to detect certain strains in certain conditions, e.g., checking phytoplasma strains during tissue culturing. In addition, several secondary applications of the multiplexPCR could be possible. For example, the entire length of several highly conserved genes, such as $16 \mathrm{~S}$ rDNA, secY, tuf, ribosomal proteins, could be amplified in one tube and a reliable phylogenetic tree could be constructed using their concatenated sequence data. Moreover, by combining highly conserved and group-specific primers, it would be easy to identify the phytoplasma group by using one PCR reaction. Further analyses will be needed to improve this multiplex-PCR system and develop new detection strategies in phytoplasma research.

\section{Acknowledgments}

Dr. Assunta Bertaccini (University of Bologna, Italy), Dr. Nishimura and Dr. Nakajima (Koibuchi College of Agriculture and Nutrition, Japan) kindly provided phytoplasma DNA samples. Dr. John Glass, Dr. Ray-Yuan Chuang, and Dr. Vladimir Noskov (J. Craig Venter Institute, USA) kindly taught us the multiplex-PCR methods. This work was supported by JSPS Kakenhi Grant Number 23681043.

\section{Literature Cited}

1. Bai, X., Zhang, J., Ewing, A., Miller, S. A., Jancso Radek, A., Shevchenko, D. V., Tsukerman, K., Walunas, T., Lapidus, A., Campbell, J. W., and Hogenhout, S. A. 2006. Living with genome instability: The adaptation of phytoplasmas to diverse environments of their insect and plant hosts. J. Bacteriol. 188:3682-3696.

2. Barbara, D. J., Morton, A., Clark, M. F., and Davies, D. L. 2002. Immunodominant membrane proteins from two phytoplasmas in the aster yellows clade (chlorante aster yellows and clover phyllody) are highly divergent in the major hydrophilic region. Microbiology 148:157-167.

3. Bekele, B., Hodgetts, J., Tomlinson, J., Boonham, N., Nikolic, P., Swarbrick, P., and Dickinson, M. 2011. Use of a real-time LAMP isothermal assay for detecting $16 \mathrm{SrII}$ and XII phytoplasmas in fruit and weeds of the Ethiopian Rift Valley. Plant Pathol. 60:345-355.

4. Bertaccini, A. 2007. Phytoplasmas: Diversity, taxonomy, and epidemiology. Frontiers Biosci. 12:673-689.

5. Blomquist, C. L., Barbara, D. J., Davies, D. L., Clark, M. F., and Kirkpatrick, B. C. 2001. An immunodominant membrane protein gene from the Western X-disease phytoplasma is distinct from those of other phytoplasmas. Microbiology 147:571-580.

6. Caliendo, A. M. 2011. Multiplex PCR and emerging technologies for the detection of respiratory pathogens. Clin. Infect. Dis. 52 Suppl. 4:S326-330.

7. Chamberlain, J. S., Gibbs, R. A., Ranier, J. E., Nguyen, P. N., and Caskey, C. T. 1988. Deletion screening of the Duchenne muscular dystrophy locus via multiplex DNA amplification. Nucleic Acids Res. 16:11141-11156.

8. Christensen, N. M., Axelsen, K. B., Nicolaisen, M., and Schulz, A. 2005. Phytoplasmas and their interactions with hosts. Trends Plant Sci. 10:526535.

9. Christensen, N. M., Nicolaisen, M., Hansen, M., and Schulz, A. 2004. Distribution of phytoplasmas in infected plants as revealed by real-time PCR and bioimaging. Mol. Plant-Microbe Interact. 17:1175-1184.

10. Davis, R. E., Zhao, Y., Dally, E. L., Lee, I. M., Jomantiene, R., and Douglas, S. M. 2013. 'Candidatus Phytoplasma pruni', a novel taxon associated with $\mathrm{X}$-disease of stone fruits, Prunus spp.: Multilocus characterization based on 16S rRNA, secY, and ribosomal protein genes. Int. J. Syst. Evol. Microbiol. 63:766-776.

11. Edwards, M. C., and Gibbs, R. A. 1994. Multiplex PCR: Advantages, development, and applications. PCR Methods Appl. 3:S65-75.

12. Firrao, G., Garcia-Chapa, M., and Marzachi, C. 2007. Phytoplasmas: Genetics, diagnosis and relationships with the plant and insect host. Front. Biosci. $12: 1353-1375$
13. Gibson, D. G., Benders, G. A., Axelrod, K. C., Zaveri, J., Algire, M. A. Moodie, M., Montague, M. G., Venter, J. C., Smith, H. O., and Hutchison, C. A., 3rd. 2008. One-step assembly in yeast of 25 overlapping DNA fragments to form a complete synthetic Mycoplasma genitalium genome. Proc. Natl. Acad. Sci. USA 105:20404-20409.

14. Grant, J. R., and Stothard, P. 2008. The CGView Server: A comparative genomics tool for circular genomes. Nucleic Acids Res. 36:W181-184.

15. Gundersen, D. E., Lee, I. M., Rehner, S. A., Davis, R. E., and Kingsbury, D. T. 1994. Phylogeny of mycoplasmalike organisms (phytoplasmas): A basis for their classification. J. Bacteriol. 176:5244-5254.

16. Hodgetts, J., Tomlinson, J., Boonham, N., Gonzalez-Martin, I., Nikolic, P., Swarbrick, P., Yankey, E., and Dickinson, M. 2011. Development of rapid in-field loop-mediated isothermal amplification (LAMP) assays for phytoplasmas. Bull. Insectol. 64:S41-S42.

17. Hogenhout, S. A., Oshima, K., Ammar, E.-D., Kakizawa, S., Kingdom, H. N., and Namba, S. 2008. Phytoplasmas: Bacteria that manipulate plants and insects. Mol. Plant Pathol. 9:403-423.

18. IRPCM. 2004. 'Candidatus Phytoplasma', a taxon for the wall-less, nonhelical prokaryotes that colonize plant phloem and insects. Int. J. Syst. Evol. Microbiol. 54:1243-1255.

19. Ishii, Y., Kakizawa, S., and Oshima, K. 2013. New ex vivo reporter assay system reveals that sigma factors of an unculturable pathogen control gene regulation involved in the host switching between insects and plants. Microbiologyopen 2(4):553-565.

20. Jomantiene, R., Davis, R. E., Maas, J., and Dally, E. L. 1998. Classification of new phytoplasmas associated with diseases of strawberry in Florida, based on analysis of 16S rRNA and ribosomal protein gene operon sequences. Int. J. Syst. Bacteriol. 48 Pt 1:269-277.

21. Jung, H. Y., Sawayanagi, T., Kakizawa, S., Nishigawa, H., Miyata, S., Oshima, K., Ugaki, M., Lee, J. T., Hibi, T., and Namba, S. 2002. 'Candidatus Phytoplasma castaneae', a novel phytoplasma taxon associated with chestnut witches' broom disease. Int. J. Syst. Evol. Microbiol. 52:15431549 .

22. Kakizawa, S., Oshima, K., Ishii, Y., Hoshi, A., Maejima, K., Jung, H. Y., Yamaji, Y., and Namba, S. 2009. Cloning of immunodominant membrane protein genes of phytoplasmas and their in planta expression. FEMS Microbiol. Lett. 293:92-101.

23. Kakizawa, S., Oshima, K., Kuboyama, T., Nishigawa, H., Jung, H. Y., Sawayanagi, T., Tsuchizaki, T., Miyata, S., Ugaki, M., and Namba, S. 2001. Cloning and expression analysis of Phytoplasma protein translocation genes. Mol. Plant-Microbe Interact. 14:1043-1050.

24. Kakizawa, S., Oshima, K., Nishigawa, H., Jung, H. Y., Wei, W., Suzuki, S., Tanaka, M., Miyata, S., Ugaki, M., and Namba, S. 2004. Secretion of immunodominant membrane protein from onion yellows phytoplasma through the Sec protein-translocation system in Escherichia coli. Microbiology 150:135-142.

25. Kim, Y., Win, N., Back, C., Yea, M., Yim, K., and Jung, H. 2011. Multiplex PCR assay for simultaneous detection of Korean quarantine phytoplasmas. Plant Pathol. 27:367-371.

26. Kube, M., Schneider, B., Kuhl, H., Dandekar, T., Heitmann, K., Migdoll, A. M., Reinhardt, R., and Seemuller, E. 2008. The linear chromosome of the plant-pathogenic mycoplasma 'Candidatus Phytoplasma mali'. BMC Genomics 9:306.

27. Laimer, M. 2009. Detection of phytoplasmas of temperate fruit trees. Methods Mol. Biol. 508:267-288

28. Lee, I. M., Bottner-Parker, K. D., Zhao, Y., Bertaccini, A., and Davis, R. E. 2012. Differentiation and classification of phytoplasmas in the pigeon pea witches'-broom group (16SrIX): An update based on multiple gene sequence analysis. Int. J. Syst. Evol. Microbiol. 62:2279-2285.

29. Lee, I. M., Gundersen-Rindal, D. E., Davis, R. E., and Bartoszyk, I. M 1998. Revised classification scheme of phytoplasmas based an RFLP analyses of 16S rRNA and ribosomal protein gene sequences. Int. J. Syst. Bacteriol. 48:1153-1169.

30. Lee, I. M., Gundersen-Rindal, D. E., Davis, R. E., Bottner, K. D., Marcone, C., and Seemuller, E. 2004. 'Candidatus Phytoplasma asteris', a novel phytoplasma taxon associated with aster yellows and related diseases. Int. J. Syst. Evol. Microbiol. 54:1037-1048.

31. Lee, I. M., Zhao, Y., and Bottner, K. D. 2006. SecY gene sequence analysis for finer differentiation of diverse strains in the aster yellows phytoplasma group. Mol Cell Probes 20:87-91.

32. Lo, K. W., Mok, C. H., Chung, G., Huang, D. P., Wong, F., Chan, M., Lee, J. C., and Tsao, S. W. 1992. Presence of p53 mutation in human cervical carcinomas associated with HPV-33 infection. Anticancer Res. 12:19891994.

33. Malembic-Maher, S., Salar, P., Filippin, L., Carle, P., Angelini, E., and Foissac, X. 2011. Genetic diversity of European phytoplasmas of the $16 \mathrm{SrV}$ taxonomic group and proposal of 'Candidatus Phytoplasma rubi'. Int. J. Syst. Evol. Microbiol. 61:2129-2134.

34. Manam, S., and Nichols, W. W. 1991. Multiplex polymerase chain reaction amplification and direct sequencing of homologous sequences: Point mutation analysis of the ras genes. Anal. Biochem. 199:106-111.

35. Marcone, C., Lee, I. M., Davis, R. E., Ragozzino, A., and Seemuller, E. 2000. Classification of aster yellows-group phytoplasmas based on combined analyses of rRNA and tuf gene sequences. Int. J. Syst. Evol. Micro- 
biol. 50 Pt 5:1703-1713.

36. McCoy, R. E., Caudwell, A., Chang, C. J., Chen, T. A., Chiykowski, L. N., Cousin, M. T., Dale De Leeuw, G. T. N., Golino, D. A., Hackett, K. J., Kirkpatrick, B. C., Marwitz, R., Petzold, H., Sinha, R. C., Suguira, M., Whitcomb, R. F., Yang, I. L., Zhu, B. M., and Seemüller, E. 1989. Plant diseases associated with mycoplasma-like organisms. Pages 546-640 in: The Mycoplasmas, Vol. 5. R. F. Whitcomb and J. G. Tully, ed. Academic Press, New York.

37. Mitrovic, J., Kakizawa, S., Duduk, B., Oshima, K., Namba, S., and Bertaccini, A. 2011. The groEL gene as an additional marker for finer differentiation of 'Candidatus Phytoplasma asteris'-related strains. Ann. Appl. Biol. 159:41-48.

38. Namba, S., Kato, S., Iwanami, S., Oyaizu, H., Shiozawa, H., and Tsuchizaki, T. 1993. Detection and differentiation of plant-pathogenic mycoplasmalike organisms using polymerase chain-reaction. Phytopathology 83:786791.

39. Nishigawa, H., Miyata, S., Oshima, K., Sawayanagi, T., Komoto, A., Kuboyama, T., Matsuda, I., Tsuchizaki, T., and Namba, S. 2001. In planta expression of a protein encoded by the extrachromosomal DNA of a phytoplasma and related to geminivirus replication proteins. Microbiology 147:507-513.

40. Nishimura, N., Nakajima, S., Sawayanagi, T., Namba, S., Shiomi, T., Matsuda, I., and Tsuchizaki, T. 1998. Transmission of Cryptotaenia japonica witches' broom and onion yellows phytoplasma by Hishimonus sellatus Uhler. Ann. Phytopathol. Soc. Jpn. 64:474-477.

41. Obura, E., Masiga, D., Wachira, F., Gurja, B., and Khan, Z. R. 2011. Detection of phytoplasma by loop-mediated isothermal amplification of DNA (LAMP). J. Microbiol. Methods 84:312-316.

42. Oshima, K., Ishii, Y., Kakizawa, S., Sugawara, K., Neriya, Y., Himeno, M., Minato, N., Miura, C., Shiraishi, T., Yamaji, Y., and Namba, S. 2011. Dramatic transcriptional changes in an intracellular parasite enable host switching between plant and insect. PLoS One 6:e23242.

43. Oshima, K., Kakizawa, S., Nishigawa, H., Jung, H. Y., Wei, W., Suzuki, S., Arashida, R., Nakata, D., Miyata, S., Ugaki, M., and Namba, S. 2004. Reductive evolution suggested from the complete genome sequence of a plant-pathogenic phytoplasma. Nature Genet. 36:27-29.

44. Rozen, S., and Skaletsky, H. 2000. Primer3 on the WWW for general users and for biologist programmers, Pages 365-386 in: Bioinformatics Methods and Protocols in the series Methods in Molecular Biology. S. Krawetz and
S. Misener, ed. Humana Press, Totowa, NJ.

45. Saccardo, F., Martini, M., Palmano, S., Ermacora, P., Scortichini, M., Loi, N., and Firrao, G. 2012. High quality genome draft of the genomes of four phytoplasma strains of the ribosomal group 16SrIII. Microbiology 158:2805-2814.

46. Suzuki, S., Oshima, K., Kakizawa, S., Arashida, R., Jung, H. Y., Yamaji, Y., Nishigawa, H., Ugaki, M., and Namba, S. 2006. Interaction between the membrane protein of a pathogen and insect microfilament complex determines insect-vector specificity. Proc. Natl. Acad. Sci. USA 103:42524257.

47. Tamura, K., Dudley, J., Nei, M., and Kumar, S. 2007. MEGA4: Molecular Evolutionary Genetics Analysis (MEGA) software version 4.0. Mol. Biol. Evol. 24:1596-1599.

48. Tao, Y., Man, J., and Wu, Y. 2012. Development of a multiplex polymerase chain reaction for simultaneous detection of wheat viruses and a phytoplasma in China. Arch. Virol. 157:1261-1267.

49. Tomlinson, J., Boonham, N., and Dickinson, M. 2010. Development and evaluation of a one-hour DNA extraction and loop-mediated isothermal amplification assay for rapid detection of phytoplasmas. Plant Pathol. 59:465-471.

50. Toth, K. F., Harrison, N., and Sears, B. B. 1994. Phylogenetic relationships among members of the class Mollicutes deduced from rps3 gene sequences. Int. J. Syst. Bacteriol. 44:119-124.

51. Tran-Nguyen, L. T., Kube, M., Schneider, B., Reinhardt, R., and Gibb, K. S. 2008. Comparative genome analysis of 'Candidatus Phytoplasma australiense' (subgroup tuf-Australia I; rp-A) and ' $\mathrm{Ca}$. Phytoplasma asteris' strains OY-M and AY-WB. J. Bacteriol. 190:3979-3991.

52. Wei, W., Kakizawa, S., Jung, H. Y., Suzuki, S., Tanaka, M., Nishigawa, H., Miyata, S., Oshima, K., Ugaki, M., Hibi, T., and Namba, S. 2004. An antibody against the SecA membrane protein of one phytoplasma reacts with those of phylogenetically different phytoplasmas. Phytopathology 94:683-686.

53. Win, N., Lee, Y., Kim, Y., Back, C., Chung, H., and Jung, H. 2012. Reclassification of aster yellows group phytoplasmas in Korea. J. Gen. Plant Pathol. 78:264-268.

54. Yankey, E., Swarbrick, P., Dickinson, M., Tomlinson, J., Boonham, N., Nipah, J., and Quaicoe, R. 2011. Improving molecular diagnostics for the detection of lethal disease phytoplasma of coconut in Ghana. Bull. Insectol. 64:S47-S48. 